\title{
Impact of Anthropogenic Activities on Genetic Variability of Yeasts inhabiting Mangrove sediments of Dar es Salaam, Tanzania
}

\author{
Eva M. Sosovele (Corresponding author) \\ Dept. of Molecular Biology \& Biotechnology, University of Dar es Salaam \\ Box 35179, Dar es Salaam, Tanzania \\ Tel: 255-784-238-836 E-mail: sosovele@gmail.com
}

Ken M. Hosea

Dept. of Molecular Biology \& Biotechnology, University of Dar es Salaam

Box 35179, Dar es Salaam, Tanzania

Tel: 255-777-486-289 E-mail: kenhosea2@gmail.com

Received: January 10, 2013 Accepted: January 28, 2013 Published: June 24, 2013

doi:10.5296/jee.v4i1.3902ＵRL: http://dx.doi.org/10.5296/jee.v4i1.3902

\begin{abstract}
The objective of the study was to investigate changes in natural yeast populations in mangrove sediments as a result of human (anthropogenic activities) disturbance. DNA techniques in form of Random amplified polymorphic DNA (RAPD) - PCR was employed in this study to assess the genetic variability of yeasts isolated from a natural sediment (non impacted) known as Ras Dege and another mangrove ecosystem which has been impacted (polluted with sewage runoffs) known as Mtoni Kijichi both along the coast of Dar es Salaam. A total of 25 morphologically different yeasts from the two mangrove sites were isolated and their genetic variability was investigated. The RAPD-PCR profiles did reveal more yeast genotypes (higher variability) in Ras Dege area compared to those at Mtoni Kijichi. Implying that, the anthropogenic activities have modified and reduced the diversity of mangrove yeasts to fewer genotypes. The results of this study points out to the negative impacts of dumping of untreated waste water in mangrove ecosystems.
\end{abstract}

Keywords: anthropogenic, activities, mangrove, yeasts, genetic, variability. 


\section{Introduction}

Mangroves are coastal wetland forests established at intertidal zones of estuaries, deltas, creeks, lagoons, marshes and mudflats of tropical and subtropical latitudes (Ananda \& Sridhar, 2004). Approximately one fourth of the world's coastline is dominated by mangroves that are distributed in 112 countries and cover about $180,000 \mathrm{~km}^{2}$ of the globe's surface in subtropical and tropical regions (Latha \& Mitra, 1998). Among marine ecosystems, mangroves constitute the second most important ecosystem in productivity. Mangrove forests are believed to be an important sink of suspended sediments (Kathiresan \& Bingham, 2001). In these forests, mangrove trees catch sediment by their complex aerial root structure, thus functioning as land builder (Holguin et al., 2001). They also generate considerable amount of detritus such as leaf litter and woody debris hence constitute an ideal environment that support or harbor diverse groups of marine animals, plants and microorganisms that are widely acknowledged to be important elements in coastal ecosystems in the tropics (Holguin et al., 2001). Mangroves preserve water quality and reduce pollution by filtering suspended materials and by assimilating dissolved nutrients, stabilize sediments and protect the shoreline from erosion.

In mangrove sediment communities, substantial fungal populations exist as part of the vast microbial diversity involved in detritus processing (Abdel-Wahab, 2005). Marine fungi (which are those that grow and sporulate exclusively in a marine or estuarine habitat) are major decomposers of woody and herbaceous substrata in marine ecosystems, where they also degrade dead animals (Kohlmeyer et al., 1996a). Marine fungi are the primary degraders of lignin, cellulose and other plant components in mangroves as they can synthesize all the necessary enzymes (Singh \& Steinke, 1992; Bremer, 1995). Marine fungi play an important role in the complex microbial mediated nutrient cycling processes and biodegradation of xenobiotics such as petroleum and its derivatives (De Araujo et al., 1995).

Yeasts are fungi that predominantly exist as unicellular organisms and at present there are about 1500 recognized yeast species which are distributed between the ascomycetes and the basidiomycetes (Kurtzman \& Fell, 2005; Botha, 2011). Yeasts play a role in maintenance of soil and sediment structure and aggregate formation. Also, Yeasts participate in soil nutrient cycles and mineralization processes. On the other hand, Yeasts serve as a nutrient source for a diversity of soil predators and they have potential as plant growth promoters and soil conditioners (Yurkov et al., 2012). However, among the marine microbiota in East Africa, it is only bacteria that have been investigated and reported (Lyimo, 1999; Machiwa, 1999; Marshal, 1994 \& Mgaya et al., 2004), leaving the potential of East African fungal diversity unfamiliar.

Anthropogenic or human impact on environment includes impacts on biotic and abiotic environments (Sahney et al., 2010). Due to the growing rate of urbanization in many tropical coastal areas, there continues to be an increasing concern on the impact of anthropogenic activities to mangrove forests (De Wolf et al., 2001; Mwevura et al., 2002; Gulis \& Subekropp, 2003; Mgaya et al., 2004; Kruitwagen et al., 2006). During recent years, Tanzania has experienced a rapid increase in urbanization and industrialization, particularly 
in the coastal area of Dar es Salaam. The mangroves ecosystems along the coast of Dar es Salaam are subject to a number of sources of pollution such as urban sewage, industrial effluents and agricultural chemicals which reach the mangroves via rivers and via direct disposal (Mgaya et al., 2004).

Dar es Salaam region of Tanzania has several mangrove stands which include Kunduchi, Selander Bridge, Mbweni, Ras Dege, Msimbazi, Mtoni Kijichi and Mji mwema (Semesi, 1998). Sewage which is water-carried waste, in solution or suspension, has long been reported to be dumped along the coast of Dar es Salaam (Machiwa, 1999). Furthermore, a wide range of sewage impacts on marine Tanzanian coastal communities has been reported (Machiwa, 1998; Gulis \& Subekropp. 2003; Kruitwagen et al., 2006).

In previous studies the sediments of the Mtoni estuary (in Dar es Salaam) were found to be polluted with polychlorinated hydrocarbons, petroleum hydrocarbons and organochlorines pesticides (Machiwa, 1998; Mwevura et al., 2002). Many of these environmental pollutants which are released into the waters of the Dar es Salaam coastal areas pass through mangrove forests before reaching the Indian Ocean coast. The mangroves and associated biota in mangrove forests, which are within the city (Mtoni Kijichi), are therefore heavily impacted by anthropogenic activities (Mremi \& Machiwa, 2003) compared with Ras Dege mangrove forests which are located a distance away from the city and hence far from human settlements (Mtanga \& Machiwa, 2007).

Elsewhere in the world, pollution has been implicated in the modification, increases or reduction of genetic diversity in various organisms in mangrove coastal ecosystems (Latha \& Mitra. 2004; Kokare et al., 2004; Limtong et al., 2007). Due to continued human interference and depletion of mangrove habitats, dangers of losing some precious fungal resources cannot be ruled out, as many are habitats/ host-specific (Latha \& Mitra. 2004).

Previous pollution studies on the coast of Tanzania have focused on the chemical analysis of environmental pollutants and their effect on higher organisms (Mremi \& Machiwa, 2003; Mtanga \& Machiwa, 2007; Rumisha et al., 2012), leaving behind a dearth of information on the effects of these pollutants on mangrove sediments microorganisms. This study therefore endeavored to isolate yeasts from both sewage impacted and non impacted mangrove sediments along the coast of Dar es Salaam and carried out a randomly amplified polymorphic DNA - PCR analysis to reveal changes in the numbers of genotypes in the yeast populations caused by the pollution.

\section{Materials and Methods}

\subsection{The Study Sites}

The two mangrove forest ecosystems (Mtoni Kijichi and Ras Dege) were selected for the intended study owing to their features; one constantly receiving sewage contamination due to proximity to human settlements and the other far from any notable pollution. 

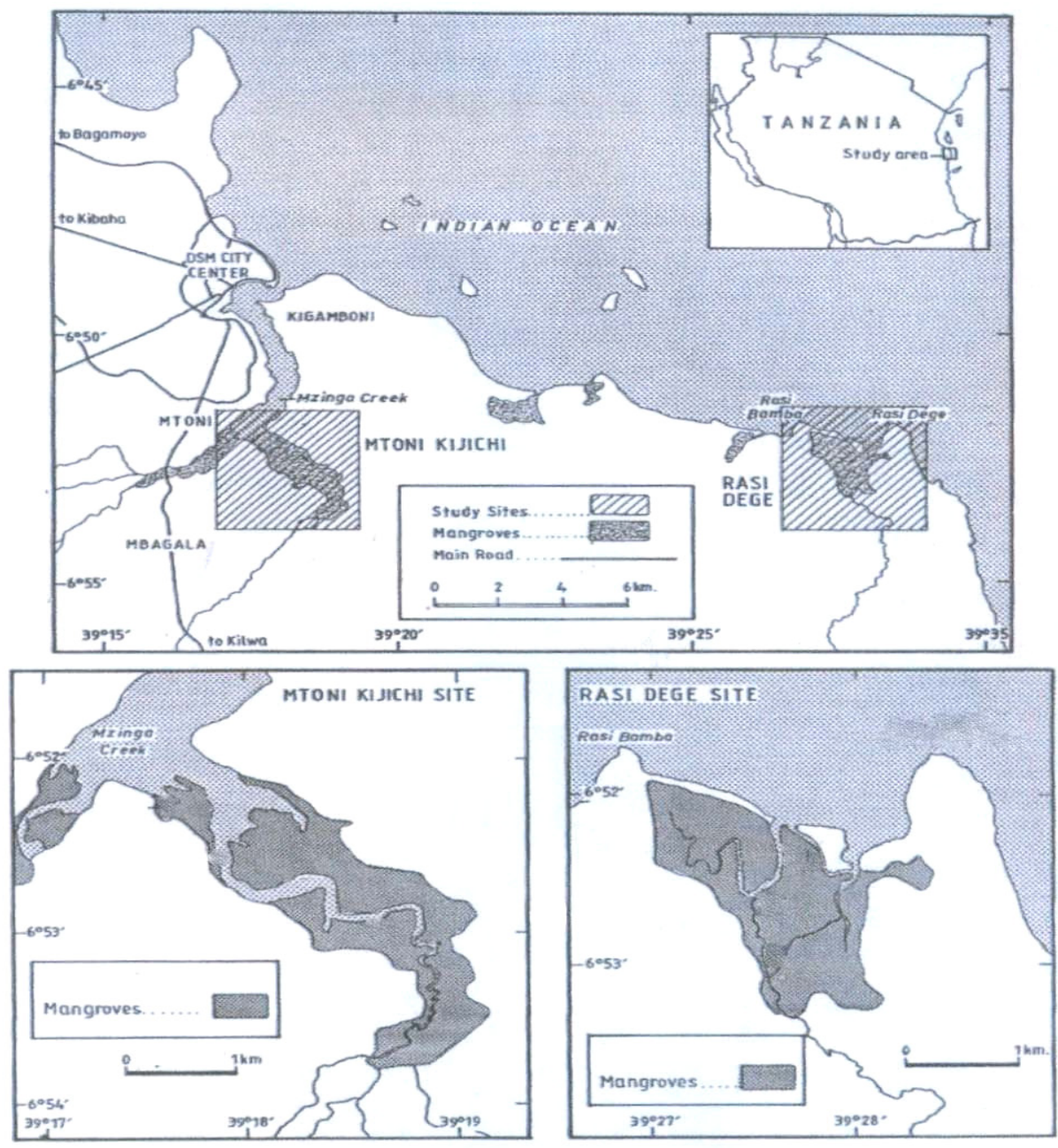

Figure 1. Map of Dar es Salaam Coast showing the study sites (Source: Abbu, 2006)

\subsubsection{Mtoni Kijichi Mangrove Site}

This site is located $15 \mathrm{~km}$ south of Dar es Salaam city centre. The mangrove forest in Mtoni Kijichi is estimated to cover 378.4 hectares. Two small permanent creeks namely Kizinga and Mzinga along with incoming rivers which are polluted with sewage run through this forest. Some streams of fresh water and seepage that may also be contaminated with sewage from nearby settlements also enter these forests (Mgaya et al., 2004).

\subsubsection{Ras Dege Mangrove Site}

Ras Dege is located along the coast approximately $60 \mathrm{~km}$ south of Dar es Salaam city center. This site lies at the mouth of Mbalaganje River and is estimated to cover about 245 hectares (Semesi, 1991). Ras Dege is considered as non sewage-impacted area as is very far from human settlements with exception of one small recreational hotel (Mbamba bay hotel) and thus experiencing very little impact from anthropogenic activities. 


\subsection{Research Methodology}

\subsubsection{The Sediment Sampling for Yeast Isolation}

Mangrove sediments were randomly selected from Ras Dege mangrove ecosystems and Mtoni Kijichi.

\subsubsection{Yeasts Isolation Methodology}

Aquatic Yeast Broth (AYB) was made by the following composition; Glucose 1\%, $\left(\mathrm{NH}_{4}\right)_{2} \mathrm{SO}_{4} 0.5 \%$, yeast extract $0.5 \%, \mathrm{NaCl} 1 \%$ and $\mathrm{NaH}_{2} \mathrm{PO}_{4} 0.2 \%$. Malt Extract Agar MEA - hyperosmotic medium was prepared according to Sosovele, 2008 and Groenewald et al., 2011, with the following composition; malt extract 5\%, saccharose $3 \%$ and $\mathrm{NaCl} 8 \% .200$ $\mu \mathrm{l}$ of sediment sample were directly inoculated into either $25 \mathrm{ml}$ Aquatic Yeast Broth (AYB) or onto an agar plate of the same media (Kurtzman \& Robnett, 1998: Sosovele, 2008; Groenewald et al., 2011). The incubation of AYB broth flasks started in the field and in the laboratory, they were incubated overnight on a shaking incubator set at $200 \mathrm{rpm}$ at $30^{\circ} \mathrm{C}$. The broth was then aseptically streaked on the Aquatic Yeast Broth (AYA) plates and incubated for two days. The agar plates which were directly inoculated with the sediment were also incubated at $30^{\circ} \mathrm{C}$ for up to two days. In case there was no growth observed after this incubation period, plates were incubated for a further two - three days. Emergent colonies were purified by the serial transfer technique. All media were made selective for fungi by including the antibiotic Ampicillin (0.02\%) after sterilization to minimize bacterial growth as successfully done in a previous study.

The pure cultures were maintained on AYA slants (Glucose 1\%, (NH4)2SO4 0.5\%, yeast extract $0.5 \%, \mathrm{NaCl} 1 \%, \mathrm{NaH} 2 \mathrm{PO} 40.2 \%$ and $2 \%$ agar). The isolates were stored at $4{ }^{\circ} \mathrm{C}$ after sub culturing after every fortnight.

\subsubsection{DNA Isolation and DNA Amplification (PCR)}

Genomic DNA (gDNAs) isolation from all yeast isolates was done as described previously (De Barros Lopez et al., (1998). The quantity of DNA was estimated by spectrophotrometric measurement of absorbance at $260 \mathrm{~nm}$ following a standard protocol (Sambrook et al., 1989). The concentration of DNA obtained in this study ranged from $50 \mathrm{ng}-100 \mathrm{ng}$. The Random Amplification of Polymorphic DNA (RAPD) PCR was done using $50 \mathrm{ng}$ gDNA as template.

The primer sequence used for the random amplifications was; Mg I (5'-CGA CTG CAG T-‘3) as used previously by Liu et al., 1996. RAPD PCR reactions were performed in $50 \mu$ volume, with $1 \mu \mathrm{l}$ (50-100 ng) of each genomic DNA template, $5 \mu 1$ reaction buffer, $2.5 \mathrm{mM} \mathrm{MgCl} 2$, $0.2 \mathrm{mM}$ each dNTPs (dATP, dGTP, dCTP, and dTTP), $0.8 \mathrm{pmol} / \mu 1$ of primer, and 1.25 units per $50 \mu 1$ of Taq DNA Polymerase. The PCR conditions included initial denaturation step for 4 minutes at $94 \mathrm{oC}$. Then, 40 cycles of denaturation for 1 minute at $94^{\circ} \mathrm{C}$, primer annealing for 60 seconds at $36^{\circ} \mathrm{C}$, extension for 2 minutes at $72^{\circ} \mathrm{C}$ and final extension for 5 minutes at $72^{\circ} \mathrm{C}$. After PCR reactions, the tubes were maintained at $4^{\circ} \mathrm{C}$ until further analysis. The RAPD products were then resolved by electrophoresis in $1.2 \%$ agarose gels stained with ethidium bromide $(0.5 \mu \mathrm{g} / \mathrm{ml})$ and TBE buffer $(0.5 \%)$ for 30 minutes following a standard protocol. 


\section{Results}

A total of 25 morphologically different yeasts from mangrove sediments of selected sites of Dar es Salaam (Ras Dege and Mtoni Kijichi) were isolated. 12 yeasts were isolated from Ras Dege sediments and 13 from Mtoni Kijichi sediments.

Table 1.List of yeast isolates from Ras Dege and Mtoni Kijichi and their code names

\begin{tabular}{|c|c|c|c|c|c|}
\hline $\mathrm{S} / \mathrm{N}$ & Code & Origin of an isolate & $\mathrm{S} / \mathrm{N}$ & Code & Origin of an isolate \\
\hline 1 & RY1 & Isolate from Ras Dege & 1 & MtY2 & Isolate from Mtoni Kijichi \\
\hline 2 & RY2 & Isolate from Ras Dege & 2 & MtY3 & Isolate from Mtoni Kijichi \\
\hline 3 & RY3 & Isolate from Ras Dege & 3 & MtY4 & Isolate from Mtoni Kijichi \\
\hline 4 & RY4 & Isolate from Ras Dege & 4 & MtY5 & Isolate from Mtoni Kijichi \\
\hline 5 & RY5 & Isolate from Ras Dege & 5 & MtY6 & Isolate from Mtoni Kijichi \\
\hline 6 & RY6 & Isolate from Ras Dege & 6 & MtY7 & Isolate from Mtoni Kijichi \\
\hline 7 & RY7 & Isolate from Ras Dege & 7 & MtY8 & Isolate from Mtoni Kijichi \\
\hline 8 & RY8 & Isolate from Ras Dege & 8 & MtY9 & Isolate from Mtoni Kijichi \\
\hline 9 & RY9 & Isolate from Ras Dege & 9 & MtY10 & Isolate from Mtoni Kijichi \\
\hline 10 & RY10 & Isolate from Ras Dege & 10 & MtY11 & Isolate from Mtoni Kijichi \\
\hline 11 & RY11 & Isolate from Ras Dege & 12 & MtY12 & Isolate from Mtoni Kijichi \\
\hline 12 & RY12 & Isolate from Ras Dege & 12 & MtY13 & Isolate from Mtoni Kijichi \\
\hline 13 & MtY1 & Isolate from Mtoni Kijichi & & & \\
\hline
\end{tabular}

\subsection{Yeast Cells Morphology}

From isolated single colonies of yeasts, microscopic examination at 400X magnification was used to arrive at a total number of 25 morphologically different yeasts. Thirteen yeast isolates were isolated from random, representative sites in the polluted mangrove sediment ecosystem (Mtoni Kijichi), and the other twelve yeast isolates were isolated from non polluted mangrove sediment ecosystem (Ras Dege).

\subsection{RAPD-PCR}

RAPD-PCR analysis of the yeast isolates from Ras Dege and Mtoni Kijichi gave distinctive patterns that permitted a clear differentiation of the considered isolates. Only $\mathrm{Mg} 1$ primer was used for RAPD analysis in this study. 


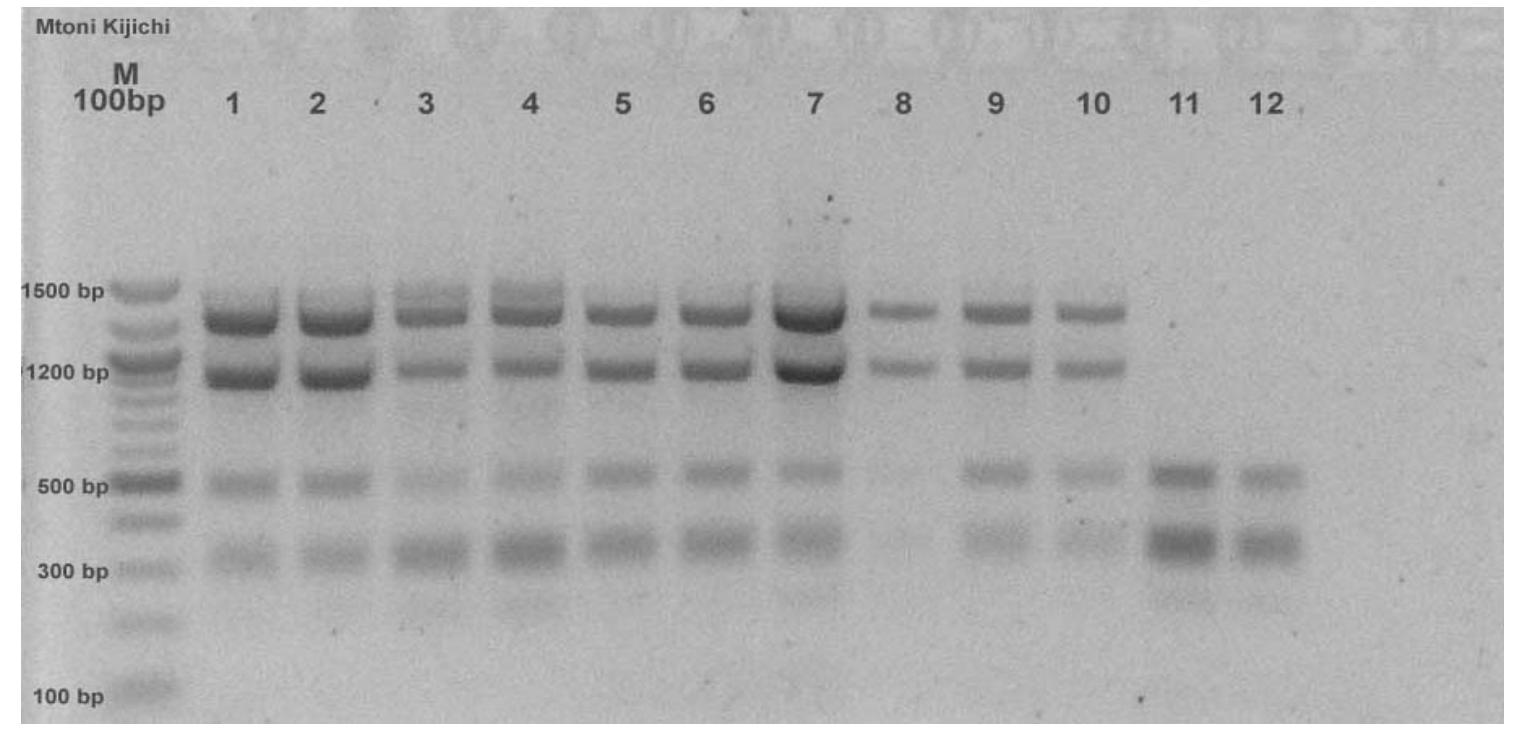

Figure 2. Results of RAPD PCR of Mtoni Kijichi (MtY) 12 yeast isolates using Mg 1 primer. Lanes 1: 100 bp markers. Lane 2 - 13: DMtY1 - 13

The results of the RAPD-PCR analysis of 12 yeast isolates from Mtoni Kijichi (a polluted ecosystem) produced two types of banding patterns (Figure 3). One type of banding patterns comprised 4 PCR bands each (Lane $2-11$ ) and the other type had only two PCR bands each (lane 12 - 13). The PCR products ranged from $300 \mathrm{bp}-1400 \mathrm{bp}$ in size as summarized in Table 2.

Table 2. Mtoni Kijichi2 Yeast Genotypes (RAPD-PCR profiles)

\begin{tabular}{|l|l|l|l|l|}
\hline Genotype & $\begin{array}{l}\text { Number of yeast } \\
\text { isolate }\end{array}$ & $\begin{array}{l}\text { Number of PCR } \\
\text { bands produced }\end{array}$ & $\begin{array}{l}\text { PCR bands size } \\
\text { range }\end{array}$ & $\begin{array}{l}\text { Yeast isolates lane/s } \\
\text { no on gel photo }\end{array}$ \\
\hline 1 & 10 & 4 & $300 \mathrm{bp}-1400 \mathrm{bp}$ & $2-11$ \\
\hline 2 & 2 & 2 & $300 \mathrm{bp}-500 \mathrm{bp}$ & $12-13$ \\
\hline
\end{tabular}

The results of the RAPD-PCR analysis of 13 yeast isolates from Ras Dege (a non polluted ecosystem) are shown in figure 4.8. Various banding PCR banding patterns were observed. 


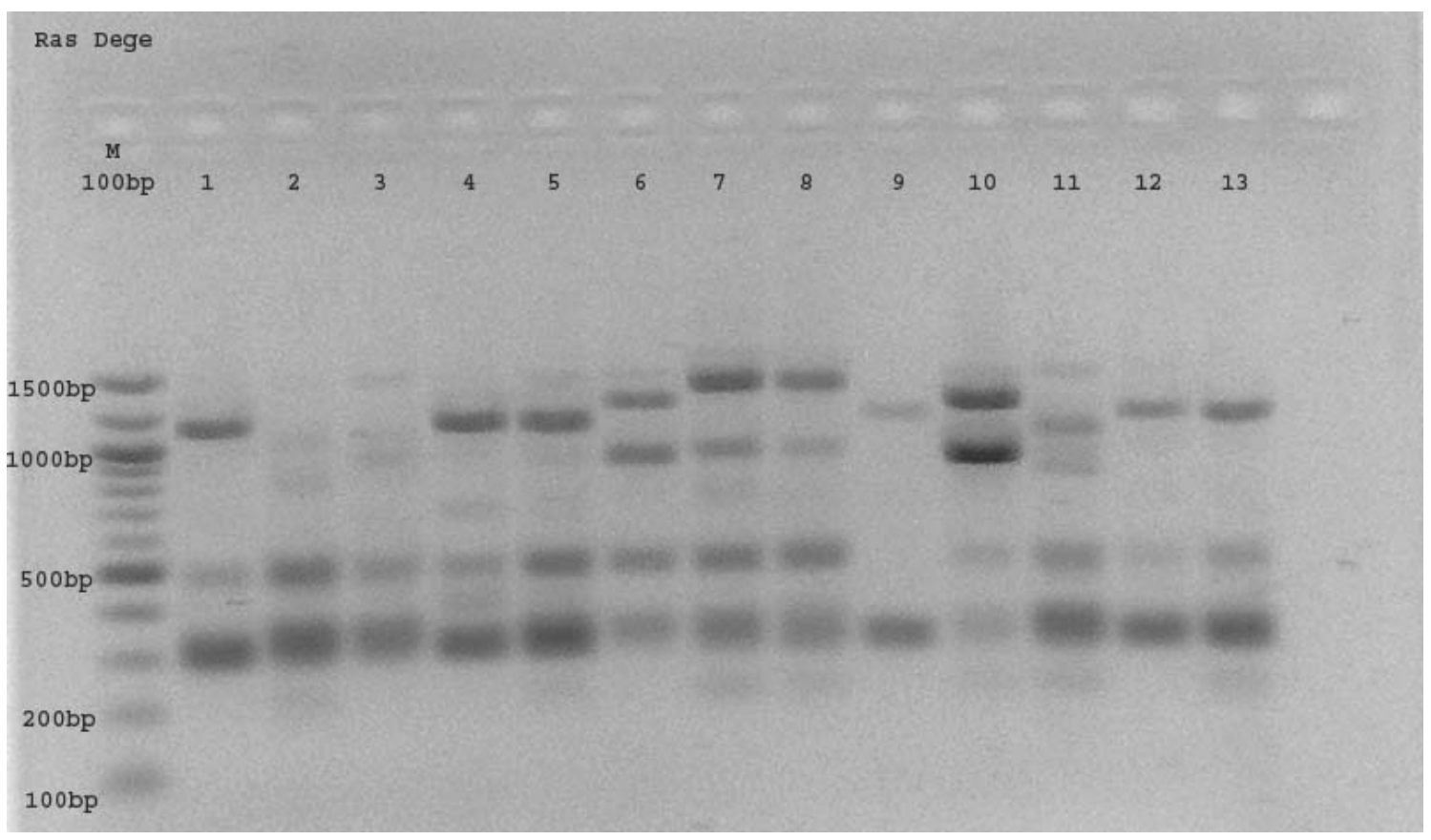

Figure 3. Results of RAPD PCR of Ras Dege (RDY) yeast isolates using Mg 1 primer. Lanes 1: 100 bp markers. Lane 2 - 13: DRDY1 - 12

5 yeast isolates produced 3 PCR bands each of the size ranging from $300 \mathrm{bp}-1200 \mathrm{bp}$ (Lane 2, 5, 6, 13 and 14), 2 yeast isolates produced 2 PCR bands of sizes $300 \mathrm{bp}$ and $500 \mathrm{bp}$ (lane 3 \& 4), 1 yeast isolate produced 4 PCR bands each (lane 7) with their sizes ranging from 300 bp $-1300 \mathrm{bp}, 1$ yeast isolate produces 2 PCR bands each and their sizes ranged from $300 \mathrm{bp}$ - $1000 \mathrm{bp}$ (lane 10), 2 yeast isolates produced 4 PCR bands each with their sizes ranging from $300 \mathrm{bp}-1500 \mathrm{bp}$ (lane $8 \&$ 9), 1 yeast isolate produced 2 bands with their sizes ranging from $1000 \mathrm{bp}-1200 \mathrm{bp}$ (lane 11) and 1 yeast isolate produced 3 bands which had sizes ranging from $300 \mathrm{bp}-1000 \mathrm{bp}$ as summarized in Table 3 below.

Table 3. Ras Dege Yeasts Genotypes (RAPD-PCR profiles)

\begin{tabular}{|l|l|l|l|l|}
\hline Genotypes & $\begin{array}{l}\text { No. Of Yeast } \\
\text { Isolate }\end{array}$ & $\begin{array}{l}\text { No. Of PCR } \\
\text { Bands Produced }\end{array}$ & $\begin{array}{l}\text { PCR Bands Size } \\
\text { Range }\end{array}$ & $\begin{array}{l}\text { Yeast Isolates } \\
\text { Lane/S No On Gel } \\
\text { Photo }\end{array}$ \\
\hline 1 & 5 & 3 & $300 \mathrm{Bp}-1200 \mathrm{Bp}$ & $2,5,6.13 \& 14$ \\
\hline 2 & 2 & 2 & $300 \mathrm{Bp}-500 \mathrm{Bp}$ & $3 \& 4$ \\
\hline 3 & 1 & 4 & $300 \mathrm{Bp}-1300 \mathrm{Bp}$ & 7 \\
\hline 4 & 2 & 4 & $300 \mathrm{Bp}-1500 \mathrm{Bp}$ & $8 \& 9$ \\
\hline 5 & 1 & 3 & $300 \mathrm{Bp}-1000 \mathrm{Bp}$ & 10 \\
\hline 6 & 1 & 2 & $300 \mathrm{Bp}-1200 \mathrm{Bp}$ & 11 \\
\hline 7 & 1 & 3 & $300 \mathrm{Bp}-1000 \mathrm{Bp}$ & 12 \\
\hline
\end{tabular}

\section{Discussion}

In this study 25 yeast isolates from two distant mangrove sediments (more than $40 \mathrm{~km}$ apart) were used to study the impact of anthropogenic activities on genetic variability of yeasts. 
The yeast isolation methodology based on selective media and streaking for single colonies was standard and has been used by various other studies (Kurtzman \& Robnet, 1998; Sosovele, 2008; Groenewald et al., 2011). However, this study may have been limited to the culturable yeast populations, and a culture independent analysis of the yeast community DNA may have revealed more information on the genotypes of the members of the yeast communities in the sediments as done in some other studies (Iacumin et al., 2009; Oguntoyinbo, 2012).

However, the results of this study as summarized in Tables 2 and 3 clearly indicate the impact of sewage pollution with only 2 genotypes of yeasts persisting in the sewage impacted mangrove sediments of Mtoni Kijichi whereas 7 genotypes were revealed in the non sewage impacted mangroves sediments of Ras Dege. The few genotypes that still survive the pollution are most likely including Candida yeasts which have been reported in other studies to dominate yeast populations in sediments impacted by human wastes (Kennish, 2001; Loureiro et al., 2005; Vogel et al., 2007: Kutty \& Phillip, 2008).

The higher number and variation of yeast genotypes observed in the non polluted sediments is in agreement with previous report of yeasts from similar ecosystems whereby various genera such as Candida, Trichosporon, Rhodotolura, Cryptococcus, Debaryomyces and Pichia were reported (Loureiro et al., 2005).

As mangroves are characterized by high population densities of microbes and other types of living organisms, these organisms tend to be highly vulnerable to human activities in coastal watersheds and adjoining embayment (Kennish, 2001). Other anticipated high priority problems are excessive nutrient and sewage inputs to mangroves which tend to modify the genetic variability of microbes and other living organisms in a particular environment (Gulis \& Subekropp. 2003; Kruitwagen et al., 2006). This appears to be the case of Mtoni Kijichi mangroves sediments which are receiving domestic sewage from nearby settlements (Mgaya et al., 2004),

The technique used in this study, RAPD PCR, is a simple analysis involving a single PCR step following extraction of DNA, It is therefore a rapid methodology for studying genetic characteristics that has been successfully used before (Pinto et al, 2004) and is recommended for similar studies.

Furthermore, it is being recommended that culture independent community DNA approach be used to analyze microbial communities in sediments the rDNA is recommended for the identification of modified yeast genotypes.

As the results of this study have clearly showed negative impacts of sewage pollution to natural ecosystems, a recommendation is being made to introduce strategies which may minimize and mitigate future pollution impacts. These may include mandatory liquid waste management systems including treatment before being discharged through the coastline into the sea. Further studies are also being proposed to be carried out within the Tanzanian mangroves for the purpose of gaining more knowledge of the fungal diversity and to step up the conservation of the mangroves which plays a vital role in the survival of the marine 
ecosystems.

\section{Acknowledgements}

The author Sosovele EM gratefully acknowledges sponsorship by the Directorate for Postgraduate Studies of the University of Dar es Salaam/NORAD support project. Author Hosea KM is expressing thanks to MARG I grants by SIDA SAREC for supporting his earliest research on marine yeasts.

\section{References}

Abbu, A. (2006). Assessment of feacal Bacteria contamination in sewage and non-sewage impacted mangrove ecosystems along coast of Dar es Salaam. MSc Dissertation (Environment Science) University of Dar es Salaam.

Abdel-Wahab A. M. (2005). Diversity of marine fungi from Egyptian Red Sea mangroves. Botanica Marina, 48, 348-355.

Ananda K \& Sridhar R. K. (2004). Diversity of Filamentous fungi on decomposing leaf and wood litter of mangrove forests in the southwest coast of India. Current science, 87(10), 1431-1437.

Botha, A. (2011). The importance and ecology of yeasts in soil. Soil Biology \& Biochemistry, 43: 1e8.

Bremer, G. B. (1995). Lower marine fungi and decay of mangrove leaf litter. Hydrobiologia, 295, 89-95.

Couto, B. M. M., van der Vossen, J. M., Hofstra, H., \& Huis in't Veld, J. H. J. (1994). RAPD analysis: a rapid technique for differentiation of spoilage yeasts. International Journal of Food Microbiology, 24, 249-260.

De Araujo, F. V., Soares, C. A., Hagler, A. N., \& Mendonca-Hagler, L. C. (1995). Ascomycetous Yeast communities of marine invertebrates in a South East Brazilian mangrove Ecosystem. Antonie van Leeuwenhoek, 68(2), 91-99.

De Barros, L. M., Soden, A., Martens, A. L., Henschke, P. A., \& Langridge, P. (1998). Differentiation: a species identification of yeasts using PCR. International Journal of Systematic Bacteriology, 48(1), 279-286.

De Wolf, H., Ulomi, S. A., Backeljay, T., Pratap, H. B., \& Blust, R. (2001). Heavy metal levels in the sediments of four Dar es Salaam mangroves; accumulation in, and effect on the morphology of periwinkle, littoraria scarbra (Mollusca: Gastropoda). Environmental International, 26, 243-249.

Groenewald, M., Robert, V., \& Smith, M. (2011). The value of the D1/D2 and internal transcribed spacers (ITS) domains for the identification of yeast species belonging to the genus Yamadazyma. Persoonia, 26, 40-46.

Gulis, V., \& Subekropp, K. (2003). Leaf litter decomposition and microbial activity in 
nutrient-enriched and unaltered reaches of a headwater stream. Freshwater Biology, 48, 123-134.

Holguin, G., Vazquez, P., \& Bashan, Y. (2001). The role of sediment microorganisms in the productivity, conservation, and rehabilitation of mangrove ecosystems. Biology and fertility of soils, 33, 265-278.

Iacumin, L., Cecchini, F., Manzano, M., Osualdini, M., Boscolo, D., Orlic, S., Comi, G. (2009). Description of the microflora of sourdoughs by culture-dependent and culture-independent methods. Food microbiology, 26(2), 12-135. http://dx.doi.org/10.1016/j.ijfoodmicro. 2008.07.017

Kathiresan, K., \& Bingham, L. (2001). Biology of Mangroves and Mangrove Ecosystems. Advances in marine Biology, 40, 81-25.

Kennish, J. M. (2001). Environmental threats and environmental future of estuaries. Environmental conservation, 29, 78-107.

Kohlmeyer, J., Volkmann-Kohlmeyer, B \& Eriksson, O. E. (1996a). Fungi on Juncus roemerianus. New marine and terrestrial ascomycetes. Mycological Research, 100, 393-404.

Kokare, C. R., Mahadik, K. R., Kadam, S. S., \& Chopade, B. A. (2004). Isolation, characterization antimicrobial activity of marine halophilic actinopolyspora species AHI from the west coast of India. Current science, 86(4).

Kruitwagen, G., Hecht, T., Pratap, B. H., \& Wendelaar-Bonga, S. (2005). Changes in morphology and growth of the mudskipper (Periophthalmus argentlineatus) associated with coastal pollution. Marine Biology, 149, 201-211.

Kurtzman, C. P., \& Fell, J. W. (2005). Yeast systematics and phylogeny - implications of molecular identifications methods for studies in ecology. In: Rosa CA and Peter G, Editors. The Yeast Handbook. Germany: Springer-Verlag berlin Herdelberg, P.11-30.

Kurtzman, C. P., \& Robnett, C. (1998). Identification and phylogeny of ascomycetous Yeasts; from analysis of nuclear large subunit (26S) ribosomal DNA partial Sequences. Ant Van Leeuwen, 73, 331-371.

Kutty, S. N., \& Philip, R. (2008). Marine yeasts - a review. Yeast, (www.interscience.wiley.com) DOI: 10.1002/yea.1599

Latha, R., \& Mitra, S. (1998). Mangrove fungi in India. Current Science, 86, 12.

Limtong, S., Yongmanitchau, W., Kawasaki, H., \& Seki, T. (2007). Candida thaimueangensis sp.nov, an anamorphic yeast species from estuarine water in a mangrove forest in Thailand. International Journal of systematic and Evolutionary Microbiolgy, 57, 650-653.

Liu, D., Coloe, S., Jones, L. S., \& Pederson, J. B. (1996). Genetic speciation of Candida isolates by arbitrarily primed polymerase chain reaction. FEMS Microbiology Letters, 145, 23-26. 
Loureiro, S. T., de Queiroz Cavalcanti, M. A., Neves, R. P., \& de Oliveira Passavante, J. Z. (2005). Yeasts isolated from sand and sea water in beaches of Olinda, Pernambuco, Brazil. Brazilian Journal of Microbiology, 36, 333-337.

Lyimo, T. J. (1999). Methanogenesis and Sulphate Reduction in Tanzanian Mangrove Sediments, Ph. D. Thesis (Applied Microbiology) University of Dar es Salaam.

Machiwa, J. F. (1998). Distribution and remineralization of organic carbon in sediments of a mangrove stand partly contaminated with sewage waste. Ambio, 27(8), 740-744.

Machiwa, J. F. (1999). Lateral fluxes of organic carbon in a mangrove forest partly contaminated with sewage waste. Mangroves and salt marshes, 3, 95-104.

Marshal, N. (1994). Mangrove conservation in relation to overall environmental considerations. Hydrobiologia, 285, 303-309.

Mgaya, Y., Machiwa, J. F., Lugomela, C., Lyimo, T. J., Muzuka, A., Shaghude, Y., Mvungi, A., Mapunda, B., \& Mwanuzi, F. (2004). Environmental Studies of Mtoni Mangrove Ecosystem, Dar es Salaam, Final report submitted to the faculty.

Mremi, S. D., \& Machiwa, J. F. (2003). Heavy metal contamination of mangrove sediments and the associated biota in Dar es Salaam, Tanzania. Tanzania Journal of Science, 29, 61-76.

Mtanga, A., \& Machiwa, J. F. (2007). Heavy metal pollution levels in water and Oysters, Saccostrea cucullata, from Mzinga creek and Ras Dege mangrove ecosystems, Tanzania. African Journal of aquatic science, 32(3), 235-244.

Mwevura, H., Othman, O. C. \& Mhehe, G. L. (2002). Organochlorine pesticide residues in sediments and biota from the coastal area of Dar es Salaam city, Tanzania. Marine pollution bulletin, 45, 262-267.

Oguntoyinbo, F. A. (2012). Culture-independent analysis for determination of yeast diversity during solid substrate fermentation of grated cassava for gari production. World Journal of $\begin{array}{llll}\text { Microbiology and 27(10), } & \text { Biotechnology, 2461-2465. }\end{array}$ http://dx.doi.org/10.1007/s11274-011-0703-9.

Pinto, M. P., Resende, A. M., Koga-Ito, Y. C., \& Tendler, M. (2004). Genetic Variability Analysis among clinical Candida species isolates using Random Amplified Polymorphic DNA. Memórias do Instituto Oswaldo Cruz, 99(2), 147-152.

Rumisha, C., Elskens, M., Leermakers, M., \& Kochzius, M. (2012). Trace metal pollution and its influence on the community structure of soft bottom mollusks in intertidal areas of the Dar es Salaam coast, Tanzania. Marine pollution Bulletin, 64(3), 521-531. http://dx.doi.org/10.1016/j.marpolbul.2011.12.025.

Sahney, S., Benton, M. J., \& Ferry, P. A. (2010). Links between global taxonomic diversity, ecological diversity and the expansion of vertebrates on land. Biology Letters, 6(4), 544-547. http://dx.doi.org/10.1016/j.marpolbul.2011.12.025

Semesi, A. K. (1991). Management Plan for the Mangrove Ecosystem of Mainland Tanzania. 


\section{Macrothink}

Volumes 1-10. Ministry of Tourism, Natural Resources and Environment, Forest and Beekeeping Division, Dar es Salaam.

Singh, N., \& Steinke, T. (1992). Colonization of decomposing leaves of Bruguier a gymnorrhiza (Rhizophoraceae) by fungi, and In vitro cellulolytic activity of the isolates, Egypt. Limnologica, 24, 525-529.

Sosovele, M. E. (2008). Genetic variability and phylogeny of yeasts from sediments of selected mangrove ecosystems of coastal regions of Tanzania. MSc thesis; University of Dar es Salaam.

Vogel, C., Rogerson, A., Schatz, S., Laubach, H., Tallman, A., \& Fell, J. (2007). Prevalence of yeasts in beach sand at three bathing beaches in South Florida. Water research, 41(9), 1915-1920. http://dx.doi.org/10.1016/j.watres.2007.02.010

Yurkov, A. M., Kemler, M., \& Begerow, D. (2012). Assessment of yeast diversity in soils under different management regimes. Fungal ecology, 5, 24-35. http://dx.doi.org/10.1016/j. funeco.2011.07.004 